\title{
FUNGICIDE PROPERTIES in Vitro OF CHITOSAN ETHYL CARBAMATE IN THE CONTROL OF VINEYARDS FUNGIES IN CHILE
}

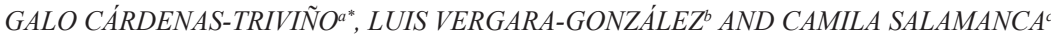 \\ ${ }^{a}$ Facultad de Ingeniería, DIMAD, Centro de Biomateriales y Nanotecnología, Universidad del Bío-Bío, \\ Av. Collao 1202, Concepción, 4051381.gcardenas@ubiobio.cl \\ ${ }^{b}$ Departamento de Biología y Química,Universidad San Sebastián, Lientur 1457, Concepción, Chile, 4080871.luisvergara@uss.cl \\ cFacultad de Ingeniería y Tecnología,Universidad San Sebastián,_Lientur 1457,Concepción, Chile, 4080871.camilasalamanca_3@hotmail.com
}

\section{ABSTRACT}

The grape table is the main fresh fruit export of Chile. However, is affected in the first place by fungal pathogens, resulting between $10 \%$ and $15 \%$ losses in production. The commercial use of biocides has a weakness generating an increase in demand for new antifungal agents. Chitosan and carbamate possess fungicidal properties; therefore the aim of this paper is to analyze the fungicidal activity of chitosan ethylcarbamate.

In vitro bioassays were carried out to evaluate the effectiveness of the fungicide to control Botrytis cinerea and Fusarium spp. fungies. The chemical composition of chitosan ethylcarbamate was determined previously. The fungi growth curves and fit with the program DMfit, which uses the Baranyi model to obtain the growth parameters were studied. Then, we estimated the MIC (minimum inhibitory concentration) by a microdilution method. These data were analyzed by simple linear regression. Growth parameters of Fusarium spp shows a growth rate of $1.3 \mathrm{~h}^{-1}$, and Botrytis cinerea of $0.9 \mathrm{~h}^{-1}$, respectively. Chitosan ethylcarbamate with a MIC of $1250 \mathrm{mg} / \mathrm{L}$ on Fusarium spp. and B. cinerea a MIC of $1250 \mathrm{mg} / \mathrm{L}$ were obtained. Finally, the chitosan ethyl carbamate fungicide, biodegradable, is a more ecological alternative to the conventional fungicides such as Iprodione, Zineb, Nabam, Maneb and the traditional Bordeaux mixture.

Keywords: Botrytis, Ethylcarbamate, Fungicides, Fusarium, Vineyards.

\section{INTRODUCTION}

A world tendency exists in favor of a greater consumption of fruits and vegetables, mainly dominated by the concern of having a more balanced diet that consists on a lower consumption of carbohydrates, fat and oil counteracted by a higher consumption of diet fiber, vitamins and minerals. The base is the reduction of the energetic expense produced by modern sedentary life. [1-2]

Table grape is the main fruit specie in the national territory. The grapevine of the table grape located from regions Antofagasta and Maule use $21 \%$ of the 212.000 cultivated acres in Chile, gathering in the Valparaiso, Metropolitana and Libertador Bernardo O’Higgins regions. [3-4]

The ASOEX, Asociación de Exportadores de frutas y hortalizas de Chile. (Chilean association of fruits and vegetables) published in 2010 that the participation of the table grape in the fruit exportations represented 36.1 of the total amount of fruits exported (847.680 exported tones) mainly exported to theUnited States, Europe and Asia.

The agriculture production is constantly limited in performance and quality due to the attack of a variety of phytophatogens such as fungi, bacteria, virus and nematodes.[5] The first one is the main group of agents that affect the metabolism of fruits and plants causing them diseases. The grey and dry rot of the table grape caused by Botrytis cinerea and Fusarium spp. respectively, are the main national phytosanitary problem of production loss that affect the grapevine in its period of pre and post-harvest.[6-7].Table grape exportation in season $2009-2011$ reached 860.000 tons, from which $10 \%$ to $15 \%$ is lost due to pathogens fungi.Later on, the Odepa from Ministry of Agriculture, published an study of the countries with higher exportation volumes, being Chile with $18.7 \%$, Italy with $13.0 \%$ and USA with $10.8 \%$ of the total market in the world. [8]

In agriculture, Chile uses at least forty types of active ingredients of pesticides that are banned in the range from your official record of the European Union. Of this total, seven fungicides force are qualified by the World Health Organization (WHO) as highly risky for the health when is exposed to certain level for it via oral and dermal. They are carbofuran, aldicarb, brodifacoum, flocoumafen, bromadiolone, tefluthrin and cadusafos [9].

The potential that have them fungicides to cause effects adverse in the human varies greatly. Historically, some of them epidemics more tragic of poisoning by fungicides have occurred through the consumption of seeds of grains that were treated with mercury organic or hexachlorobenzene. Is likely that several of the fungicides that are used today cause mild or severe poisonings frequent or systemic due to several reasons [10]:

- First of all, many of them have a toxicity inherent low to the mammals and are absorbed inefficiently. Secondly, many fungicides are formulated in a suspension of dust and water absorbent granules, so it is likely a quick and efficient absorption. And thirdly, the methods of application are such that individuals who are highly exposed. Apart from the systemic poison, fungicides, in its class, are probably responsible for a disproportionate number of irritants damage to skin, mucous membranes and skin sensitization.

- According to a report by the Institute of Public Health (2010), citizen of consumers League asked the company Nestlé Chile withdraw all your foods for babies, where residues of iprodione were found. Ensures the grouping that iprodione can produce carcinogenic effects in those who consume it. Nestle withdrew products. According to the studies made by ISP, the products cast threw indexes of $0.41 \mathrm{mg} / \mathrm{Kg}$ of the fungicide, upper to the limit maximum allowed $0.01 \mathrm{mg} / \mathrm{Kg}$ that sets the European standard [11].

The chemical control of these diseases is based on the use of fungicides, a toxic substance use to kill fungi. The presence of plaguicide residues is a limitation of the exports and the absence of an antidote in case of an intoxication from some of the fungi promotes the need for developing new fungicides.[12]

Due to the previously mentioned, it is suggested to determine and compare in vitro the efficiency of the chitosan ethylcarbamate and of two commercial products for fungi control that cause the grey and dry rot that affects the vineyards (Vitis spp.) in Chile.

The minimal inhibitory concentration (MIC) of chitosan ethylcarbamate over Botrytis cinerea and Fusarium spp.will be obtained.By mentioned, arises to assess the efficacy of the product chitosan ethyl carbamate on fungal species that attack the vines of table grapes, in order to incorporate into the Chilean market a fungicide biocompatible and biodegradable, applicable to organic and non-organic crops of fruit.

\section{MATERIALS AND METHODS}

Chitosan ethylcarbamate solution.

Achitosan ethylcarbamate $2 \%$ aqueous solution (viscosity $=125$ centipoisses) was prepared for fungal studies.[13-14]

TGA studies exhibit in the DTGA two peaks at 244 and $354^{\circ} \mathrm{C}$, respectively. Corresponding to carbamate and chitosan. 


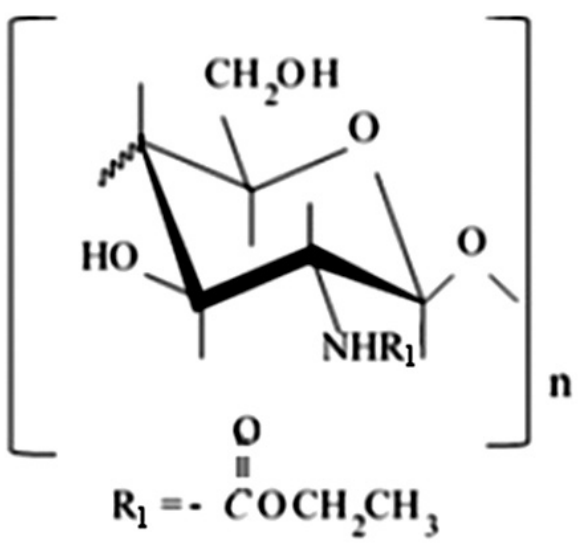

Figure 1.Chemical structure of Chitosan Ethyl Carbamate

\section{Bordeaux mixture elaboration}

The composition of the Bordeaux mixture is of $10 \mathrm{~g} / \mathrm{L}$ of Calcium hydroxide $\left(\mathrm{Ca}(\mathrm{OH})_{2}\right)$ and $10 \mathrm{~g} / \mathrm{Lpentahydrated} \mathrm{copper} \mathrm{sulfate} \mathrm{in} 600 \mathrm{~mL}$ of water. The calcium hydroxide is prepared until complete dissolution using a magnetic stirrer.Separately, in $300 \mathrm{~mL}$ of water the copper sulfate with magnetic stirring is dissolved at $30^{\circ} \mathrm{C}$. After that and slowly, the coppe solution is added over the calcium hydroxide solution, water is also added until complete a liter.[15]

\section{Iprodione elaboration}

A solution of Iprodione (3-(3,5-dichlorophenyl)- $N$-isopropyl-2,4dioxoimidazolidine-1-carboxamide) is prepared at $50 \%$, which is $0,75 \mathrm{~g} / \mathrm{L}$ in water based on the indications of the technical instructions of the Rukon $50 \mathrm{WP} \circledast$ product obtained in Bioleche S.A. The structure is as follow:<smiles>CC(C)NC(=O)N1CC(=O)N(c2cc(Cl)cc(Cl)c2)C1=O</smiles>

Figure 2. Chemical structure of iprodione.

\section{Grapevine acquire}

The $B$. cinerea grape wine was obtained from the fungies collection of the Civil Engineering in biotechnology of the Universidad San Sebastián, while Fusarium spp. was obtained by isolation of grape wine infested branches.

\section{Culture medium for filamentous fungi}

A PDA (potato dextrose agar) culture medium is prepared in distilled water in a concentration of $39 \mathrm{~g} / \mathrm{L}$ of water. The culture medium to increase the fungi is sterilized in autoclave at $121^{\circ} \mathrm{C}$ temperature and At $1 \mathrm{~atm}$ pressure for $15 \mathrm{~min}$. The plate with inoculant fungi are incubated in a culture oven at $20^{\circ} \mathrm{C}$ for 15 days.

\section{Procedure for fungi isolation}

Samples that show the presence of pathogens using magnifying glasses are taken from branches of grapevine with sterile scalpel and forceps. These pathogens are spread in Petri plates with PDA medium and incubated for 3 days. The fungi developed are separated in new Petri plates with PDA medium until spores can be visualized. The samples are incubated for 7 days at $20^{\circ} \mathrm{C}$ This last procedure is repeated one more time with the objective of isolate the fungi and they are identified using the reproductive structures. To identify them, Barnett [16] methods are used.

\section{Fungi growth curve}

Fungi growth curve is obtained when charting the diameter of the colonies versus the time and they adjusted with the DMfit program that uses Barany model (equation 1) to determine the growing parameters [17] growing speed, latency period and maximum growing.

$$
y(t)=y_{0}+\mu_{\max } t+\frac{1}{\mu_{\max }} \ln \left(e^{-v \cdot t}+e^{-h_{0}}-e^{-v \cdot t-h_{0}}\right)-\frac{1}{m} \ln \left(1+\frac{e^{m \mu_{\max } t+\frac{1}{\mu_{\max }} \ln \left(e^{-v \cdot t}+e^{-h_{0}}-e^{-v \cdot t-h_{0}}\right)}-1}{e^{m\left(y_{\max }-y_{0}\right)}}\right) \quad(y(t):
$$


Where:

$y(t)$ : colonies diameter.

$y_{0}:$ : initial diameter.

$\mu_{\max }$ : growing specific speed $\mathrm{h}^{-1}$.

$m$ :curvature parameter to characterize the transition of the experimental phase.

$V$ :curvature parameter to characterize the transition of the exponential phase.

$h_{0}$ :non dimention parameter that quantifies the initial physiological state of the cells.

$h:$ :It is calculated as. $h_{0} / \mu_{\max }$

Determining the sensibility of the pathogens to fungi agents.

The microdilution EUCAST 9.1 from 2008 method isused for testing sensitivityin vitro of the filamentous fungi in the presence of fungicides through determining MIC (Minimum inhibitory concentration) over the Bordeaux mixture, iprodione and chitosan ethylcarbamate.[18]

\section{Results analysis}

In order to make the adjustments of the growth curves based on the Baranyi model of 1994, the average of the three repeated samples justified by the data spread grade.

In the statistical analysis of the experimental variables of optical density against the concentration of the fungicides in the present study, a random block design with 11 factors or treatments corresponding to the concentration of the fungicides distributed in two blocks that represents both grapevines of filamentous fungi, with their respective statistical model was used.

$$
Y_{i j}=\mu+\alpha_{i}+\beta_{j}+\varepsilon_{i j}
$$

for $i=1, \ldots$, a y $j=1, \ldots, b$, being

$\square:$ The global medial effect

$\square_{i}$ : The incremental effect over the media caused by the level $i$ of the $A$ factor

1 : The incremental effect over the media caused by the level $j$ of the $B$ block

$\square_{i j}:$ The error term.

\section{RESULTS AND DISCUSSIONS}

\section{Isolated fungi in the vineyard branches.}

From the extract of the vineyard branches cultures were made and the predominant fungi is isolated. According to Barnett identification keys, we determine which fungi corresponds to Fusarium spp. Macroscopic and

(A)

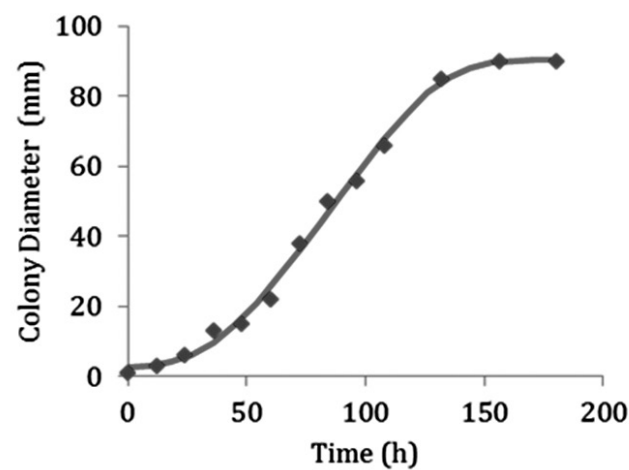

Figure 5. (A) Growing curve of Botrytis cinerea in potato dextrose agar(B) Growing curve of Fusariumspp.in potato dextrose agar. microscopic characteristics are observed through a microscopy.
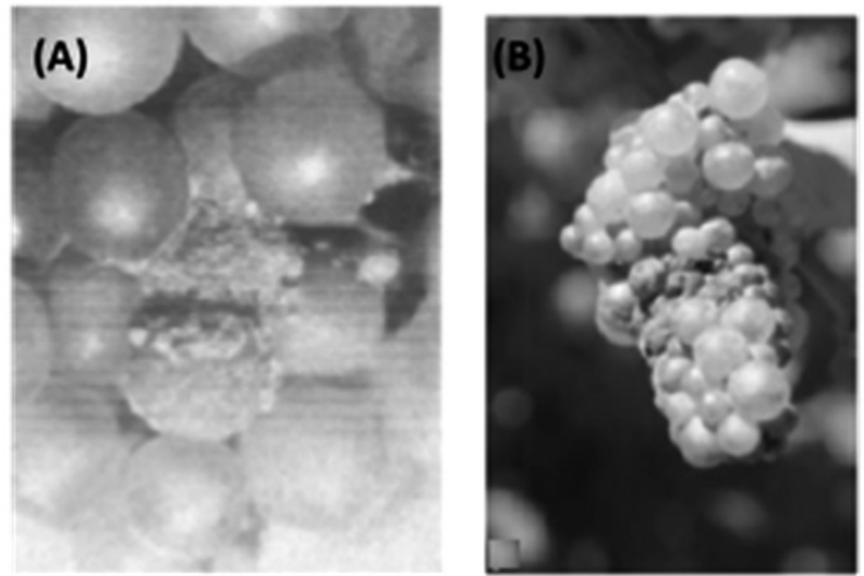

Figure 3. Botrytis cinerea (A) the fungi gray or rot of the cluster of grapes. (B) rot and the decrease of the berries in the part of the cluster of grapes due to the Botrytis infestation.[6]

\section{Macroscopic characteristics}

Colonies grow $9 \mathrm{~cm}$ diameter in 6 days at $25^{\circ} \mathrm{C}$. They are velvet yellowwhite color and on the back they are purple like shown in Figure 4.

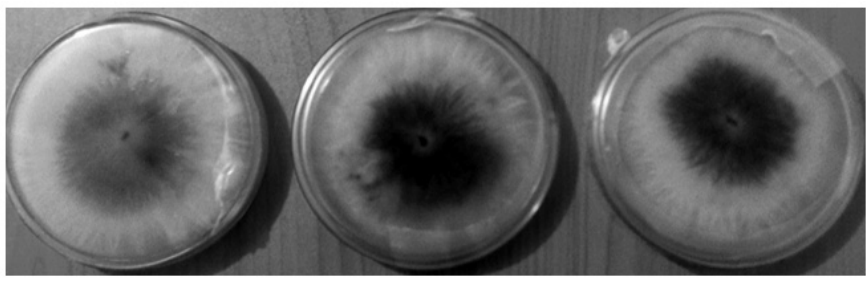

Figure 4. Fusarium spp. in PDA medium.

\section{Microscopic characteristics}

Septal and septum conidium, macroconidea and macroconidea from 0 to 5 septus with shapes: oval-ellipsoidal and slightly curve are observed.

\section{Filamentous fungi growing curve}

B. cinerea and Fusariumspp. are cultured in Petri plates with PDA medium to develop growing curves to study the fungi behavior.

Figures 5 shows the filamentous fungi growing curve at $20^{\circ} \mathrm{C}$ using potatoes dextrose agar.

\section{(B)}

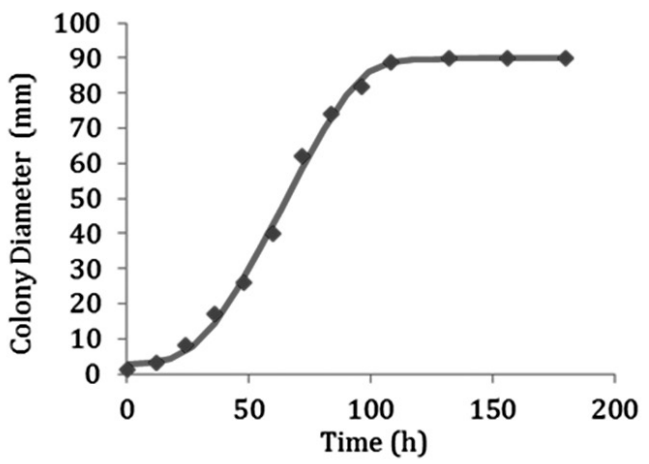


The growing of the filamentous fungi described the growing curve of the fungi with sigmoid shape. Table [a] shows the maximum growth of $9 \mathrm{~cm}$ in B. cinereaat 156 hours (6.5 days) and of Fusariumspp. at 132 hours (5.5 days). Both growths are delimitated by the diameter of the Petri culture plate. The latent time is the time of the fungi in the latent zone of growing. Both fungi have a latent phase lower to 40 hours, and then start with growing speed parameters was related to the intrinsic characteristics of each fungi.[19]

Each experiment was carried out three times. The average to make the adjustments of the data in the growing curve of the filamentous fungi was considered.

Table 1. Growing parameters of Botrytis cinerea and Fusarium spp.

\begin{tabular}{|c|c|c|}
\hline Growing parameter & Botrytis cinerea & Fusarium spp. \\
\hline Growing speed $(1 / \mathrm{h})$ & 0,9078 & 1,3304 \\
\hline Latent time $(\mathrm{h})$ & 39 & 22 \\
\hline Maximum growth $(\mathrm{mm})$ & 90 & 90 \\
\hline
\end{tabular}

(A)

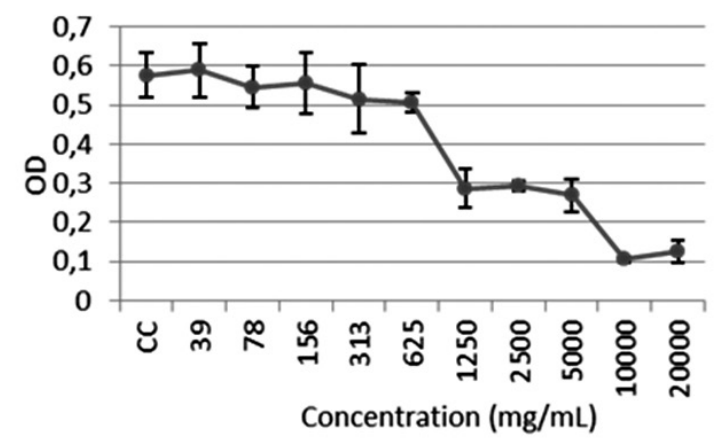
near to $1 / \mathrm{h}$. See Table 1 . In general, the observed behavior from the growing

\section{Spore count on the filamentous fungi}

The spore count of Fusarium spp. in Neubauer chamber indicates a spore suspension of $1.92 \times 10^{6} \mathrm{cel} / \mathrm{mL}$, which was diluted in sterile distilled wate at a ratio $1: 10$ in order to obtain a final concentration of $1.92 \times 10^{5} \mathrm{cel} / \mathrm{mL}$. Septal macrocon idea with moon shape and microcon idea with oval shape are observed and indicated with arrows.

Spore count in Neubauer chamber of Botrytis cinerea indicates a spore suspension of $2.85 \times 10^{6}$ of $\mathrm{cel} / \mathrm{mL}$, which was diluted in sterile distilled water at a ratio of $1: 10$ to obtain a final concentration of $2.85 \times 10^{5} \mathrm{cel} / \mathrm{mL}$. The oval conidia are observed.

\subsection{Botrytis cinerea sensitivity to chitosan ethylcarbamate}

The response curve against the chitosan ethylcarbamate fungicide variation of the Figure 4 shows that low concentrations of the fungicide do not present inhibitory effect over the fungi growing, and at higher concentrations a reduction in the optical density of $50 \%$ is produced. At a $10.000 \mathrm{mg} / \mathrm{L}$ to $20.000 \mathrm{mg} / \mathrm{L}$ concentrations, the chitosan ethylcarbamate presents a fungicide action over the $B$. cinerea fungus.

(B)

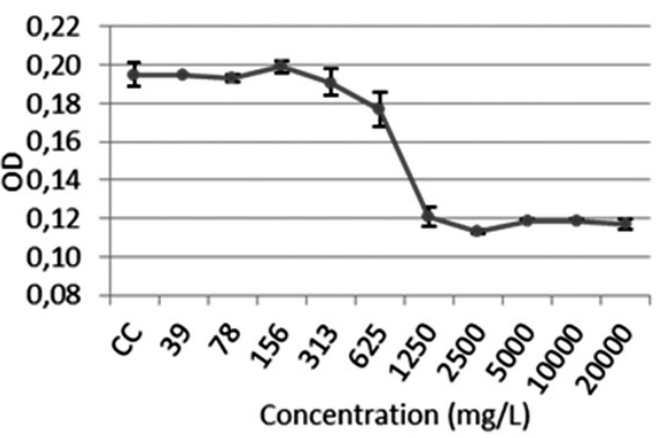

Figure 6. (A) Effect of the chitosan ethyl carbamate over B. cinerea growing. OD: Optical density in absorbance and G.C: Growing control. (B) Effect of the chitosan ethyl carbamate over Fusarium spp. growing. OD: Optical density in absorbance and G.C: Growing control.

\section{Fusarium spp. sensitivity to chitosan ethylcarbamate}

The response curve against the chitosan ethylcarbamate fungicide concentration variation shows that low concentrations of the fungicide has no biocide effect over the fungi growing and when increases the concentration, a decrease of $62 \%$ the optical density is produced, therefore MIC is of $1250 \mathrm{mg}$ / mL.At this point, chitosan ethylcarbamate presents a fungicide action over $B$. cinerea fungus.

The chitosan presents an antifungal activity that mainly affect the mycelial growth, sporulation, germination and morphology of spores and hyphae[19] and the carbamate has a fungicide action which inhibits the cholinesterase in the cell metabolism[20]. This product is presented as a homogenous liquid, inhibiting the fungi growing, see Figure 6 (B).

\section{CONCLUSIONS}

The fungi growing curves present a latent time of 39 hours for $B$. cinerea and 22 hours for Fusarium spp. and a growing speed of $0,9078 \mathrm{~h}^{-1}$ for $B$. cinerea and of $1,3304 \mathrm{~h}^{-1}$ for Fusarium spp. These parameters were used for the sensitivity tests against fungicides with the objective of keeping a growing control on the microdilution plate bowls.

The MIC of the chitosan ethylcarbamate over Botrytis cinerea is of 1250 $\mathrm{mg} / \mathrm{L}$, and over Fusarium spp. of $1250 \mathrm{mg} / \mathrm{mL}$. It was not possible to determine the MIC neither of the Bordeaux mixture nor of the iprodione, since the solutions decanted and prevented the optical density reading. But from literature some data reported $100 \mu \mathrm{g} / \mathrm{mL}$ for iprodione and/or fenexamid with $25 \mathrm{~g} / \mathrm{mL}$, which are quite lower that chitosan carbamate, but the residual time are several weeks and they are more contaminant and not biodegradable products.

The chitosan ethylcarbamate is a product easy to apply that do not pollute the environment or contaminate humans, it has biocompatible and biodegradable characteristics. Its lethal nature was determined over the filamentous fungi but it could not be compared with the one from Bordeaux mixture or from the iprodione through microdilution method of the Eucast 9.1 procedure.

\section{ACKNOWLEDGEMENTS}

The authors would like to thank Quitoquimica Ltda. for the lab facilities and chitosan ethyl carbamate for testing.

\section{REFERENCES}

[1] E. Rodríguez, Revista científica de sociedad, cultural y desarrollo sostenible. 7, 153-170, (2011)

[2] S. Olivares, Prevención del sobrepeso y obesidad, INTA, pp. 93-108, 2002.Available in: www.inta.cl/material_educativo/CD/5Obesid.pdf

[3] E. Ferreyra, G. Sellés, I. Sellés, Boletín 60, (2001). Available in: http:// www.inia.cl/medios/biblioteca/boletines/NR27126.pdf

[4] K. González, Evaluación de la eficacia e agentes biocontroladores sobre la expresión de la enfermedad de postcosecha "Ojo de Buey" causado po Neofabraea alba en manzana Pink Lady, Memoria de título para optar al título de ingeniero agrónomo, Universidad de Talca, Talca, Chile, (2006).

[5] B.A Latorre, C Lillo, M.E Rioja, Cien. Inv. Agr. 28 (2), 61-66, (2001).

[6] G Agrios, Plant Pathology. Editorial Elsevier Academic Press $5^{\text {a }}$ edición. 
New York, EE.UU. 72, 338, 388, 512 p, 2005.

[7] L Ciampi, S Radic, E Álvarez.Patología vegetal micológica. Editorial Nueva Firenze, $1^{\mathrm{a}}$ edición, 153-154, 165-167, 2006.

[8] J. Bravo, Mercado de la uva de mesa. Oficina de estudios y políticas agrarias. Ministerio de Agricultura, Santiago, Chile, 2010. Available in: http:// www.odepa.gob.cl/odepaweb/publicaciones/doc/2405.pdf. Accessed 14 Jun 2011.

[9] O. Fernández, Al menos 40 tipos de pesticidas no permitidos en Europa se usan en Chile, La Segunda 1 de febrero de 201, disponible en http://www. lasegunda.com/Noticias/Nacional/2011/02/621845/Al-menos-40-tiposde-pesticidas-no-permitidos-en-Europa-se-usan-en-Chile consultado 16 de septiembre de 2011.

[10]J. Routt, J Roberts, Reconocimiento y manejo de los envenenamientos, $5^{\mathrm{a}}$ edición, disponible en www.epa.gov/pesticides/safety/healthcare consultado 17 de septiembre de 2011.

[11] Instituto de Salud Pública, Chile, 2010 (www. isp.gob.cl)

[12]H. Hernández, E. Águila, O. Flores, E.L Viveros, E. Ramos, Superficies y Vacio22(3), pp. 57-60, (2009)

[13]G. Cárdenas, J. Paredes, G. Cabrera, P.Cassals, J.Appl. PolymerScience, 86, 2742-2747, (2002)
[14] M.L Carrillo, M.R Ramírez, J.C Martínez, Cienc. Tecnol. Aliment. 5 (2), 142-146, (2006).

[15] J. Restrepo, Caldos Minerales, Impresos Feriva S.A. (2007), Cali, Colombia.

[16]H.L Barnett. Imperfect Fungi. Editorial Burgess Publishing Company. $2^{\mathrm{a}}$ edición. Minneapolis, EE.UU. 1-9, 61, 73, 1965.

[17] M.L Carrillo, D Zavala, B. Alvarado, Información tecnológica, 18 (4), pp. 100-106, (2007).

[18] J.L Rodríguez, M.C Arendrup, S Arikan, F Barchiesi, J Bille, E Chryssanthou., M Cuenca,E Dannaoui, D.W Denning, J.P Donnelly, W Fegeler, C Lass, C Moore, M Richardson, P Gaustad, A Schmalreck, A Velegraki, P Verweij, Method for the determination of broth dilution minimum inhibitory concentrations of antifungal agents for conidia forming moulds, EUCAST (European Committee for Antimicrobial Susceptibility Testing), (2008). Available: www.eucast.org.Accessed 26 Jun 2011.

[19] S Bautista, L Bravo, Revista Iberoamericana de Tecnología Postcosecha, 6 (001), pp. 63-67, (2004).

[20] A Hernández, S Bautista, M Gerardo,Revista Mexicana de Fitopatología 23 (002), pp. 198-205, (2005) 